НАУКОВИЙ ВІСНИК

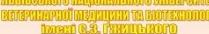

entific messenger of Livi vationet

2.

11 WIMI

4 .

СЕРЯ: ХАРчОВ технолОГО

Том 22 № 94

2020

\section{Науковий вісник Яьвівського національного університету} ветеринарної медицини та біотехнологій імені С.3. Гжицького.

Серія: Харчові технології

\section{Scientific Messenger of Lviv National University} of Veterinary Medicine and Biotechnologies.

Series: Food Technologies

ISSN 2519-268X print

ISSN 2707-5885 online doi: 10.32718/nvlvet-f9415

https://nvlvet.com.ua/index.php/food

UDC 664.144.069.852:613.292

\title{
Research of the process of foaming of marshmallow mass with synbiotic
}

\author{
H. Korkach, O. Kotuzaki, V. Tolstykh, H. Shunko \\ Odessa National Academy of Food Technologies, Odessa, Ukraine
}

Article info

Received 14.09.2020

Received in revised form 15.10.2020

Accepted 16.10.2020

Odessa National Academy of Food Technologies, Kanatna Str., 112,

Odessa, 65039, Ukraine.

Tel: $+38-063-699-70-12$

E-mail:kor2007@ukr.net
Korkach, H., Kotuzaki, O., Tolstykh, V., \& Shunko, H. (2020). Research of the process of foaming of marshmallow mass with synbiotic. Scientific Messenger of Lviv National University of Veterinary Medicine and Biotechnologies. Series: Food Technologies, 22(94), 80-86. doi: $10.32718 /$ nvlvet-f9415

Considering that today intestinal dysbiosis to some extent affects about $90 \%$ of the population of Ukraine, it is advisable to develop confectionery products with functional ingredients that can affect the microflora and are used to restore the disturbed balance of intestinal ecostructure. Such ingredients include synbiotics. This paper substantiates the need to develop recipes for confectioneries, including marshmallows, to create new types of pastilles with functional properties. Marshmallow production includes the usage of egg whites in fresh, frozen, or dried form as a foaming agent. In recent years, companies use dry egg whites, which have a number of advantages: increasing the sanitary level of production, reducing production area, improving safety and quality stability of finished products that included it in the formula. The functional and technological properties of dry egg whites have been studied regarding the possibility of obtaining pastille products with high-quality stable foam structure. It has been experimentally established that dry protein should be reduced at $30 \ldots 40{ }^{\circ} \mathrm{C}$ and the optimal foaming ability of the protein is at $40 \ldots 45^{\circ} \mathrm{C}$. The regularities of the foaming process in confectionery masses with a synbiotic have been determined. It has been found that the marshmallow mass with microencapsulated bifidobacteria and lactulose (5; 7.5; and $10 \%$ requires 6, 5 and 4 minutes of whisking at 400 rpm to form foam, respectively, whereas the control sample required 8 minutes. The dependence of quality indicators of marshmallow masses (density and air volume concentration) on the foaming temperature has been studied. It has been established that the production of marshmallow mass with a synbiotic of a certain density occurs at $38{ }^{\circ} \mathrm{C}$ and the study of air volume concentration confirms that the maximum temperature allowing to produce a high-quality mass is $40^{\circ} \mathrm{C}$. Thus, the whisking temperature required to obtain high-quality and stable foam has been experimentally determined for the marshmallow mass. This research allows us to state with confidence that introducing a synbiotic complex into the structure of a marshmallow mass improves the foaming process which allows to produce high-quality products with soft texture and stable foam structure.

Key words: synbiotic, dysbiosis, functional ingredients, marshmallow mass, foaming, egg whites, density, foam, air volume concentration, temperature.

\section{Дослідження процесу піноутворення зефірної маси з синбіотиком}

\author{
Г. В. Коркач, О. М. Котузаки, В. Ю. Толстих, Г. С. Шунько
}

Одеська національна академія харчових технологій, м. Одеса, Украӥна

Враховуючи, що на сьогодні дисбактеріозом кишечнику в тій чи іншій мірі страждає близько 90 \% населення Украӥни, доцільним є розроблення кондитерських виробів з функціональними інгредієнтами, які здатні впливати на стан мікрофлори $і$ використовуються для відновлення порушеної рівноваги кишкової екоструктури. Саме до таких інгредієнтів належать синбіотики. У роботі обтрунтовано необхідність розробки рецептур кондитерських виробів, зокрема зефіру, для створення нових видів пастильних виробів з функиіональною спрямованістю. При виготовленні зефіру на виробництві як піноутворювач використовують яєчний білок у свіжому, замороженому або сухому вигляді. В останні роки підприємства використовують як піноутворювач сухий яєчний білок, використання якого у виробництві має цілу низку переваг - підвищення санітарного рівня власного виробництва, зменшення виробничої площі, безпека і стабільність якості готових виробів, до рецептур яких він входить. Досліджено функиіональнотехнологічні властивості сухого яєчного білка для можливості одержання готових пастильних виробів з якісною, стабільною, 
стійкою пінною структурою. Експериментально встановлено, щуо доиільно проводити відновлення сухого білка при температурі $30 \ldots 40{ }^{\circ} \mathrm{C}$, а оптимальна піноутворююча здатність білка забезпечується в інтервалі температур - від 40 до $45^{\circ} \mathrm{C}$. Визначено закономірності процесу піноутворення збивних кондитерських мас з синбіотиком і встановлено, шуо при інтенсивності збивання зефірної маси 400 об/хв для дослідних зразків з внесенням мікрокапсульованих біфідобактерій і лактулози в кількості 5; 7,5 і 10 \% час утворення піни складає відповідно 6, 5 i 4 хв, тоді як у контрольного зразка ией час - 8 хв. Досліджено залежність якісних показників зефірних мас - густини та об'ємної концентрації повітря - від температури піноутворення. Встановлено, ияо одержання зефірної маси з синбіотиком визначеної густини відбувається при температурі $38{ }^{\circ} \mathrm{C} i$ за показниками об 'ємної концентрації повітря підтверджено, що гранична температура, при якій можна одержати масу високої якості, складає $40{ }^{\circ} \mathrm{C}$. Тобто експериментально визначено температуру збивання зефірної маси для одержання якісної $і$ стійкої піни. Проведений комплекс досліджень дозволяє з впевненістю стверджувати, щуо при введенні до складу зефірної маси синбіотичного комплексу поліпшується процес піноутворення зефірної маси, щуо дозволить одержати готові вироби високої якості, які мають ніжну консистенцію та стійку пінну структуру.

Ключові слова: синбіотик, дисбіоз, функціональні інгредієнти, зефірна маса, піноутворення, яєчний білок, густина, піна, об' 'мна концентрація повітря, температура.

\section{Ветуп}

Спосіб життя і харчування - найважливіші фактори, які забезпечують здоров'я людини, ії здатність до праці, захист від хвороб і шкідливих впливів, підтримку активного довголіття, можливість протистояти зовнішнім несприятливим факторам. Саме ці чинники визначають якість життя і його тривалість. Водночас сучасний етап розвитку людського суспільства характеризується як видатними досягненнями в галузі науки, техніки, технології, так і виникненням і наростанням екологічних проблем, нервово-емоційних навантажень, стресових ситуацій, зміною ритму життя і харчування.

В останні роки до хвороб “цивілізації” приєдналися захворювання шлунково-кишкового тракту (ШКТ), зокрема дисбіози. Однією 3 причин поширення дисбіозів є значне погіршення екологічної ситуації на планеті: підвищився радіаційний фон, зросли рівні забруднення повітря, води, грунту, продуктів харчування шкідливими хімічними сполуками, радіонуклеотидами; має місце широке застосування антимікробних, протипухлинних, гормональних, проносних, жовчогінних та інших медичних препаратів. Дисбіоз ШКТ вважається одним 3 найважливіших факторів, що впливає на розвиток багатьох шлунковокишкових захворювань, таких як запальні хвороби кишечнику, синдром подразненого кишечнику, рак ободової і прямої кишки, а також системних захворювань, таких як ожиріння, цукровий діабет, атеросклероз i неалкогольний жировий гепатоз (PerisBondia et al., 2011; Fava \& Danese, 2011; Marushko \& Asonov, 2018).

За даними сучасних епідеміологічних досліджень, дисбактеріозом кишечнику в тій чи іншій мірі страждає близько 90 \% населення планети (Zajkov, 2008). Для характеристики дисбактеріозу кишечнику в різні роки були запропоновані різноманітні класифікації, що враховують вид мікробної флори, тип порушень, тяжкість перебігу та клінічні форми. Але універсальної класифікації не існує. У даний час умовно виділяють чотири стадії (ступеня) кишкового дисбактеріозу (Kim \& Ho, 2010; Prakash et al., 2011; Cimmerman, 2013). У початкових (I і II) стадіях дисбіозу кишечнику, що протікають без явних клінічних симптомів, призначають функціональне харчування, при якому до складу харчового раціону входять продукти рослинного, тваринного і мікробного походження, які містять харчові волокна, біфідо- і лактобактерії, природні антиоксиданти (пектини, протеїни, вітаміни, мінеральні речовини та ін.), пребіотики, які образно називаються поживними ліками. 3 їх допомогою вдається нерідко відновити мікрофлору товстої кишки в короткі терміни, не вдаючись до прийому фармакологічних засобів (Kostjukevich, 2011; Cimmerman, 2013; Dubinina, 2016). Тому важливо створювати харчові продукти, зокрема i кондитерські вироби, 3 функціональними інгредієнтами, які здатні впливати на нормалізацію мікробіоценозу людини.

Сьогодні кондитерська галузь вирішує цілу низку найважливіших завдань щодо поліпшення споживчих властивостей, підвищення біологічної цінності продукції, що випускається, розроблення широкої асортиментної лінійки виробів, які б надавали певного фізіологічного ефекту і володіли профілактичними властивостями. Тому перед науковцями стоїть завдання розробки і впровадження в виробництво виробів функціонального харчування, які надають регулюючу дію на організм людини і здатні замінити частину лікарських препаратів.

До теперішнього часу світовий ринок функціональних кондитерських виробів залишається нішевим, проте зростає дуже швидко, оскільки виробники солодощів шукають нові шляхи диференціації своєї продукції від продукції конкурентів. На думку експертів, цей ринок буде продовжувати свій активний розвиток і в середньостроковій перспективі.

Розроблена велика кількість продуктів 3 функціональними властивостями: одні поповнюють організм людини мікронутрієнтами, інші - поліпшуюють травлення, користь третіх полягає у позитивному впливі на імунну, серцево-судинну, нервову системи тощо. Проте й досі існує прогалина в асортименті продуктів, які відновлюють мікрофлору кишечнику. Синбіотики за своїми властивостями підходять для вирішення даного завдання. Тобто, одним 3 перспективних напрямків, які відкривають великі можливості для розширення асортименту кондитерських виробів з функціональною спрямованістю, є використання синбіотичних комплексів в технології кондитерських виробів. А вироби з використанням синбіотиків можуть бути призначені не тільки людям, які страждають захворюваннями ШКТ, а й усім, хто дбає про своє здоров'я.

Але, на жаль, у даний час в кондитерській галузі України відсутній випуск виробів 3 використанням пробіотиків та синбіотиків. Однак в Росії фахівці 
НВО “Артлайф” розробили кондитерські вироби нових видів, збагачені різними мікронутрієнтами, під загальною назвою "Цукерки молочні збагачені". “Ацидомілк”, “Біфідомілк”, “Лактомілк” - вироби загальнозміцнюючої дії, служать засобом для нормалізації мікрофлори ШКТ, підвищення загальної резистентності організму, профілактики розвитку дисбактеріозу внаслідок впливу різних чинників, у тому числі й тих, що виникають після прийому антибіотиків і сульфаніламідних препаратів (Poznjakovskij et al., 2005).

Відомі розробки по вивченню нових видів жирової начинки 3 внесенням у рецептуру як пробіотиків біфідо- і лактобактерій (Krasina et al., 2008). У роботі (Krasina et al., 2014) запропоновано використання в рецептурі жирової начинки пробіотиків - Біфілакта А і Біфілакта Д, а також пребіотика Beneo ${ }^{\mathrm{TM}}$ Synergy1.

Також вирішенню даної проблеми присвячено ряд робіт вітчизняних (Dorokhovych \& Lyman, 2010; Dorohovich et al., 2015) та зарубіжних (Mandal et al., 2013; Konar et al., 2016; Kemsawasd et al., 2016; Rad et al., 2018) вчених.

Однак розробок з використанням синбіотиків в технології кондитерських виробів на сьогодні дуже мало, тому актуальним і доцільним є проведення досліджень щодо внесенню до рецептури зефіру як функціонального інгредієнту синбіотичного комплексу.

Метою роботи є дослідження процесу піноутворення зефірної маси з синбіотиком.

Відповідно до поставленої мети необхідно вирішити такі завдання:

- визначити якість піноутворювача для одержання зефірної маси $з$ певними структурно-механічними властивостями;

- дослідити вплив інтенсивності збивання на густину зефірної маси з синбіотиком;

- з'ясувати вплив температури збивання на густину зефірної маси з синбіотиком та об'ємну концентрацію повітря.

\section{Матеріал і методи досліджень}

Експериментальна частина роботи виконана на кафедрі технології хліба, кондитерських, макаронних виробів і харчоконцентратів Одеської національної академії харчових технологій. Дослідження включали розроблення синбіотичного комплексу, який складався із лактулози з масовою часткою 5; 7,5 і 10 \%, i мікрокапсульованих біфідобактерій в кількості $15 \times 10^{7} \mathrm{KУО} / \Gamma$ зефіру; вивчення функціональнотехнологічних властивостей яєчного білка та встановлення оптимальних технологічних параметрів для одержання зефірної маси визначеної якості.

Сировина, яка використовувалась для досліджень, відповідала ДСТУ та вимогам діючої в Україні нормативної документації.

Піноутворюючу здатність білкових сумішей визначали за методикою Barilko-Pikielka, наведеною у роботі (Sushanskij \& Lifljandskij, 1999).

Густину зефірної маси визначали волюмометричним методом (Iorhachova et al., 2011).
Визначення об'ємної конщентрації повітря в збивних масах згідно (Iorhachova et al., 2011).

Зефірну масу в лабораторних умовах готували традиційним способом на розробленій експериментальній установці (Iorhachova et al., 2011). Для проведення аналізу зефірної масу збивали в збивальній машині. Час збивання встановлювали, керуючись метою експерименту.

\section{Результати та їх обговорення}

Піноподібні кондитерські маси, зокрема зефір,це висококонцентровані системи з просторовою піноподібною структурою. Через сильно розвинену поверхню поділу фаз піни $є$ термодинамічно нестійкими системами і прагнуть до мимовільного руйнування структури. У збивних кондитерських масах рідкі плівки, що розділяють бульбашки газу, утворюють в сукупності цукрово-білково-фруктовий золь, здатний переходити в гель. Завдяки механічним властивостям адсорбційної плівки структура піноподібних кондитерських виробів може зберігатися тривалий час. Якість виробів піноподібної структури обумовлюється рецептурними факторами - присутністю і співвідношенням різних видів сировини, концентрацією піноутворювача і його природою, загальною концентрацією сухих речовин у рецептурній суміші і технологічними параметрами: температурою, тривалістю збивання, а також способом отримання маси, $\mathrm{pH}$ середовища та іншими факторами (Krugljakov \& Ekserova, 1990; Zubchenko, 2001).

При розробці рецептури зефіру з синбіотичним комплексом як контрольний зразок взято рецептуру зефіру “Біло-рожевий”. У попередніх роботах (Korkach \& Borovik, 2014; Korkach et al., 2014; Korkach, 2015) докладно розглянуто доцільність створення синбіотичного комплексу і обгрунтовано оптимальне співвідношення його компонентів.

Для оцінки якості піноутворюючої здатності розчинів і утворених із них пін користуються різними критеріями, тому що універсального критерію, який однозначно оцінює якість піни у будь-яких масах, не існує. Можна виділити основні властивості, які всебічно характеризують піну (зефірну масу) - піноутворення та піностійкість. Тому в роботі вивчено вплив різних чинників на піноутворення кондитерських дисперсних мас.

При проведенні досліджень збивання рецептурної суміші проводили на експериментальній установці. Приготування зефірної маси в лабораторних умовах проводилося за традиційною технологією 3 такими змінами: при виробництві зефіру з добавками внесення лактулози проводили на стадії збивання рецептурної суміші (одночасно з яєчним білком, цукромпіском, пектиновою сумішшю і емульсією з фарби та есенції). Збивання рецептурної суміші здійснювалося при температурі $38^{\circ} \mathrm{C}$ протягом 2-3 хв при частоті 400 об/хв. Після цього додавали цукрово-патоковий сироп температурою $85 . .90^{\circ} \mathrm{C}$ і збивали ще 2 хв. Потім вносили суміш мікрокапсульованих бактерій i збивали протягом 1 хв. 
При виробництві зефіру на виробництві як піноутворювач використовують яєчний білок у свіжому, замороженому або сухому вигляді. Від якості білка залежать структурно-механічні властивості отриманої збитої зефірної маси і показники якості готового зефіpy.

В останні роки підприємства використовують як піноутворювач сухий яєчний білок, застосування якого у виробництві має цілу низку переваг - підвищення санітарного рівня власного виробництва, зменшення виробничої площі, безпека і стабільність якості готових виробів, до рецептур яких він входить. Сухий яєчний білок легко дозується і має тривалий (до 1 року) термін зберігання. Але для отримання хорошої якості готової продукції необхідно підібрати білок $з$ визначеними функціонально-технологічними властивостями для можливості одержання готових пастильних виробів 3 якісною, стабільною, стійкою пінною структурою. Для використання сухих яєчних продуктів на виробництві необхідно оптимально підібрати умови для їх відновлення. Також сухий яєчний білок у вигляді тонкодисперсного порошку має тенденцію до злежування і утворення нерівномірних агрегатів. Це зменшує питому поверхню, що негативно позначається на процесі збивання і на якості готового зефіру. 3 метою збільшення питомої поверхні сухого яєчного білка необхідно його попередньо дезагрегувати на вібростолах.

Для використання сухого білка у технології зефіру, він повинен набрякнути в воді. Дослідження щодо визначення тривалості набрякання сухого яєчного білка проводили при температурних режимах від $15^{\circ} \mathrm{C}$ до $50{ }^{\circ} \mathrm{C}$ (рис. 1$)$.

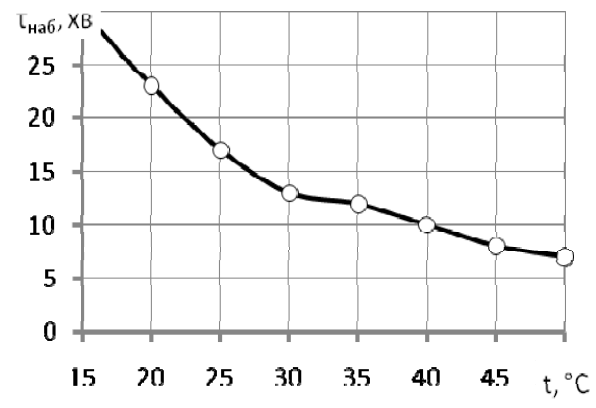

Рис. 1. Залежність тривалості набухання яєчного білку від температури

При температурі $15^{\circ} \mathrm{C}$ (що відповідає мінімальній температурі технологічної води в зимовий період без додаткового підігрівання) набухання білка здійснювалося протягом 30 хв. Із підвищенням температури до $40{ }^{\circ} \mathrm{C}$ тривалість набухання білка зменшується і становить 10 хв, а після підвищення температури понад $40{ }^{\circ} \mathrm{C}$ змінюється незначно. Це пояснюється тим, що 3 підвищенням температури зростає швидкість руху молекул яєчного білка і прискорюється процес осмотичного проникнення води в макромолекули білка. Виходячи із одержаних результатів, рекомендовано проводити відновлення сухого яєчного білка при температурі $30 \ldots 40^{\circ} \mathrm{C}$.
Також доцільно дослідити вплив температури на піноутворюючу здатність сухого яєчного білка (рис. 2).

Піноутворююча здатність білка зростає 3 підвищенням температури від $15{ }^{\circ} \mathrm{C}$ до $45{ }^{\circ} \mathrm{C}$ і максимальне значення досягається при температурі $45^{\circ} \mathrm{C}$, а після підвищення температури до $50 \mathrm{C}$ починає знижуватися, що викликано коагуляцією білка. Отже, оптимальна піноутворююча здатність сухого яєчного білка забезпечується в інтервалі температур - від 40 до $45^{\circ} \mathrm{C}$.

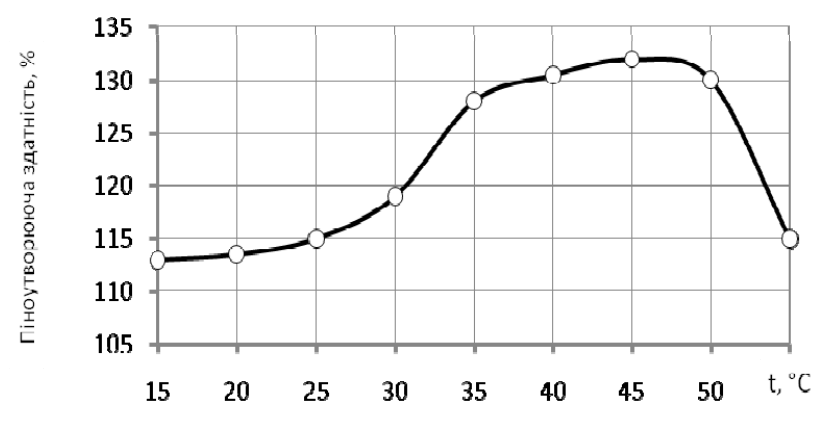

Рис. 2. Залежність піноутворюючої здатності сухого яєчного білка від температури

На стадії збивання маси основним технологічним завданням $є$ отримання піни 3 рівномірним розподілом бульбашок повітря і значною часткою повітряної фази, що відіграє одну з основних ролей у формуванні смакових властивостей і якості зефіру. Показниками, що дозволяють визначити якість одержуваних пін, $\epsilon$ їхня густина і дисперсність.

Надзвичайно ніжна, таюча текстура зефіру формується за рахунок значного вмісту повітряної фази i рівномірної пористості виробів. Тому одним 3 ключових параметрів, що впливають на споживчі характеристики кінцевого виробу, є густина зефірної маси, яка для якісного виробу не перевищує 500 кг/м³

Досліджено вплив інтенсивності збивання на густину мас при постійному часі збивання (рис. 3).

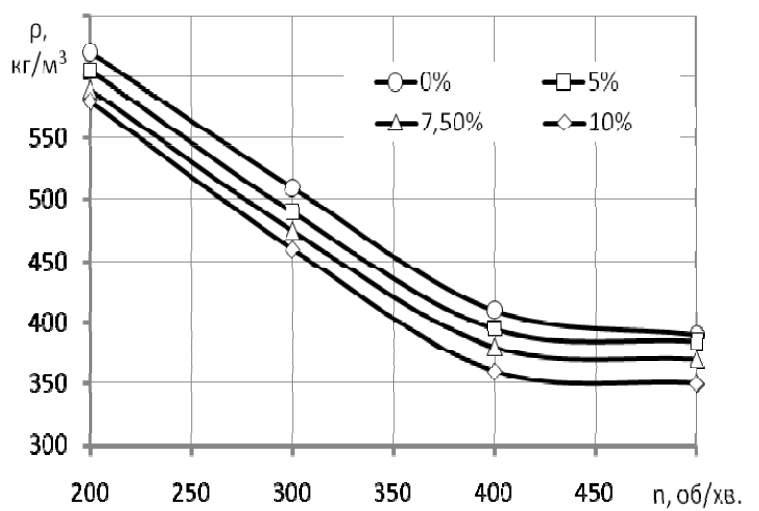

Рис. 3. Вплив інтенсивності збивання на густину маси з мікрокапсульованими біфідобактеріями та лактулозою: 1 - 0; 2 - $5 \% ; 3-7,5 \% ; 4-10 \%$

При малих значеннях частоти обертання робочих органів (200 об/хв) зефірна маса має досить велике значення густини, тому що в початковий період збивання одночасно протікають процеси утворення i ділення бульбашок, система інтенсивно насичується 
повітрям. При подальшому збільшенні частоти обертання робочих органів до 300 об/хв і 400 об/хв густина маси знижується i, досягнувши значення

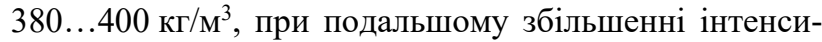
вності збивання залишається постійною. Тому збільшення частоти обертання понад 400 об/хв не тільки не інтенсифікує процес, а й призводить до перевитрати енергії, що незадовільно позначиться на економічних показниках роботи підприємства. Оптимальна інтенсивність збивання складає 400 об/хв.

Досліджували також вплив інтенсивності збивання на тривалість збивання маси необхідної густини $\left(400 \pm 20 \kappa г / \mathrm{M}^{3}\right)$. Тривалість збивання залежить від конструкції машини, частоти обертання валу, форми лопатей і їхнього розташування, від розмірів завантаження машини. Зі збільшенням часу збивання обсяг піни підвищується, покращується іiї дисперсність, а отже, і стійкість. Однак тривалість збивання має свою межу, вище якої обсяг піни зменшується, погіршується ії якість і стійкість.

Встановлено (рис. 4), що при збільшенні інтенсивності збивання для одержання маси необхідної густини час збивання зменшується. При інтенсивності збивання 400 об/хв для дослідних зразків 3 внесенням мікрокапсульованих біфідобактерій i лактулози в кількості 5; 7,5 і $10 \%$ час утворення піни складає відповідно 6, 5 і 4 хв, тимчасом як у контрольного зразка цей час -8 хв. Відбувається зниження часу утворення піни з підвищенням інтенсивності збивання і збільшенням масової частки лактулози у зефірній мaci.

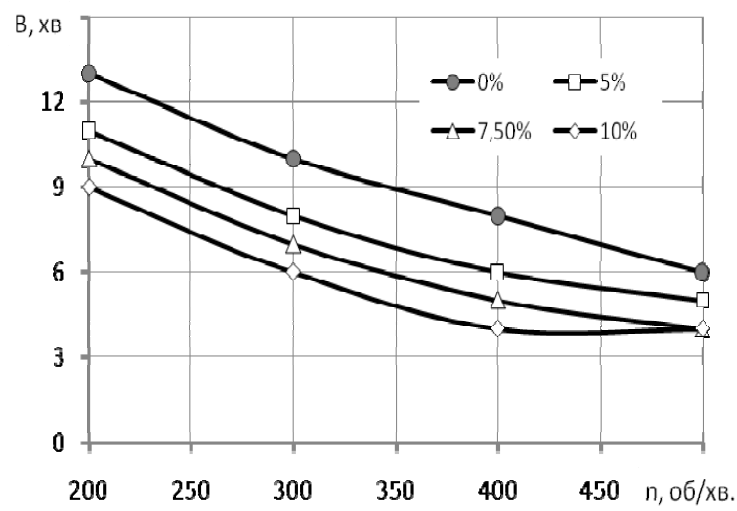

Рис. 4. Вплив інтенсивності збивання на тривалість утворення піни заданої густини маси 3 мікрокапсульованими біфідобактеріями та лактулозою: 1 - 0; 2 - $5 \% ; 3-7,5 \% ; 4-10 \%$
Одним з найважливіших технологічних параметрів піноутворення $є$ температура. Досліджено залежність якісних показників зефірних мас - густини та об'ємної концентрації повітря - від температури піноутворення. Вплив температури на піноутворюючу здатність пов'язаний з дією великого числа факторів. 3 підвищенням температури підвищується тиск усередині бульбашок, збільшується розчинність поверхнево-активних речовин (ПАР), зменшується поверхневий натяг. Ці чинники сприяють піноутворенню i піностійкості. Однак при підвищенні температури посилюються теплові коливання адсорбованих молекул i, отже, послаблюється механічна міцність поверхневого шару, утвореного молекулами ПАР. Крім того, в'язкість піноутворюючого розчину знижується, що підвищує швидкість витікання рідини 3 піни, а також змінюються умови гідратації полярних груп ПАР, що викликає зменшення стійкості піни (Ekserova et al., 1983).

Встановлено залежність густини зефірних мас 3 використанням синбіотиків від температури піноутворення (рис. 5).

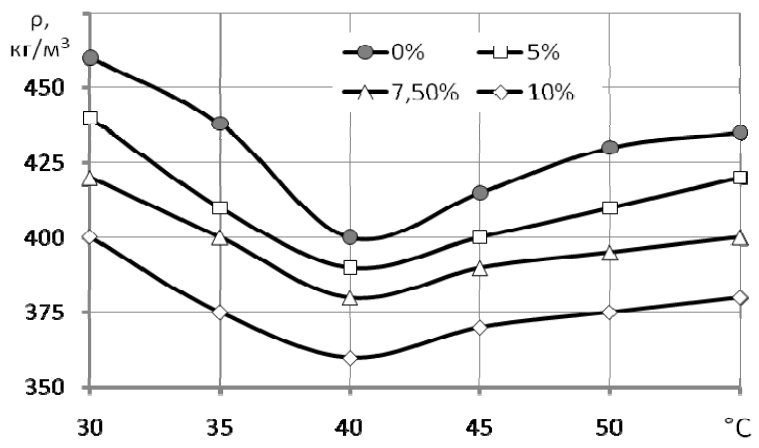

Рис. 5. Вплив температури збивання на густину зефірної маси з мікрокапсульованими біфідобактеріями та лактулозою: 1 - 0; 2 - $5 \% ; 3-7,5 \% ; 4-10 \%$

3 підвищенням температури суміші зменшується поверхневий натяг і в'язкість рідкої фази, що сприяє підійманню піни, насиченню пухирцями повітря, внаслідок чого відбувається зниження густини зефірної маси. Але при температурі $40{ }^{\circ} \mathrm{C}$ і вище відбувається підвищення густини піни. Тому оптимальною температурою виробництва зефірної маси з синбіотиком вибрано $38^{\circ} \mathrm{C}$.

Досліджено зміну об'ємної концентрації повітря зефірної маси 3 синбіотиками від температури (табл. 1).

\section{Таблиця 1}

Зміна об’ ємної концентрації повітря зефірної маси з синбіотиками від температури $(n=5, \mathrm{P} \leq 0,05)$

\begin{tabular}{|c|c|c|c|c|}
\hline \multirow{2}{*}{$\begin{array}{l}\text { Температура } \\
\text { збивання, }{ }^{\circ} \mathrm{C}\end{array}$} & \multicolumn{4}{|c|}{$\begin{array}{c}\text { Об’ємна концентрація повітря зефірної маси з мікрокапсульованими біфідобактеріями } 10^{7} \text { KУО/г } \\
\text { та лактулозою }\end{array}$} \\
\hline & 0 & 5 & 7,5 & 10 \\
\hline 30 & 0,7 & 0,72 & 0,76 & 0,77 \\
\hline 35 & 0,76 & 0,79 & 0,82 & 0,84 \\
\hline 40 & 0,75 & 0,78 & 0,81 & 0,84 \\
\hline 45 & 0,74 & 0,76 & 0,78 & 0,81 \\
\hline 50 & 0,72 & 0,73 & 0,75 & 0,78 \\
\hline 55 & 0,67 & 0,7 & 0,71 & 0,75 \\
\hline
\end{tabular}


При підвищенні температури в процесі отримання зефірної маси відбувається підвищення тиску всередині бульбашок, зменшується поверхневий натяг, що сприяє проведенню процесу піноутворення. Однак при подальшому підвищенню температури посилюються теплові коливання адсорбованих молекул i, отже, послаблюється механічна міцність поверхневого шару, зменшується концентрація повітря у зефірній масі, відбувається підвищення густини маси. Гранична температура, при якій можна одержати масу високої якості, складає $40{ }^{\circ} \mathrm{C}$.

\section{Висновки}

1. Аналітичні та теоретичні дослідження стану наукової проблеми за працями вітчизняних та зарубіжних вчених дозволили визначити доцільність розробки і впровадження в технологію зефіру синбіотичного комплексу, який складається з пребіотика - лактулози, та пробіотика - мікрокапсульованих біфідобактерій.

2. 3'ясовано вплив температурних параметрів на піноутворюючу здатність сухого яєчного білка та експериментально встановлено, що доцільно проводити відновлення сухого білка при температурі $30 \ldots 40{ }^{\circ} \mathrm{C}$, оптимальна піноутворююча здатність білка забезпечується в інтервалі температур - від 40 до $45{ }^{\circ} \mathrm{C}$.

3. Визначено закономірності процесу піноутворення збивних кондитерських мас 3 синбіотиком i встановлені раціональні технологічні параметри отримання виробів дрібнопористої структури з густиною $400 \pm 20 \mathrm{\kappa г} / \mathrm{M}^{3}, t=38^{\circ} \mathrm{C}, n=400$ об/хв, $\tau_{\text {збив }}=4$ 6 хв.

Перспективи подальших досліджень. Результати досліджень підтверджують перспективність та доцільність введення в рецептуру зефіру синбіотичного комплексу. Подальші дослідження будуть спрямовані на вивчення структурно-механічних та фізикохімічних властивостей зефірної маси з синбіотиком.

\section{References}

Cimmerman, Ja. S. (2013). Jeubioz i disbioz zheludochno-kishechnogo trakta: mify i real'nost'. Klinicheskaja medicina, 1, 4-11. URL: https://cyberleninka.ru/article/n/eubioz-i-disbiozzheludochno-kishechnogo-trakta-mify-i-realii (in Russian).

Dorohovich, A. N., Murzin, A. V., \& Pasechnik, E. V. (2015). Ispol'zovanie prebiotika laktulozy pri proizvodstve fruktovo-jagodnyh nachinok. Materialy V Mezhdunarodnoj nauchno-tehnicheskoj konferencii: Novoe v tehnologii i tehnika funkcional'nyh produktov pitanija na osnove mediko-biologicheskih vozzrenij, g. Voronezh, 4-5 ijunja 2015g., 250-253 (in Russian).

Dorokhovych, A. M., \& Lyman, N. A. (2010). Vykorystannia laktulozy pry vyrobnytstvi keksiv. Khlibopekarska i kondyterska promyslovist Ukrainy, 2, 3-5. URL: http://dspace.nuft.edu.ua/jspui/bitstream/123456789/346/ 1/lactulose_cake_production.pdf (in Ukrainian).
Dubinina, N. V. (2016). Formirovanie mikroflory kishechnika i ee vlijanie na zdorov'e cheloveka i processy starenija. Problemy starenija i dolgoletija, 25(1), 23-30. URL: http://geront.kiev.ua/library/psid/t25/ n1/Dubinina.pdf (in Russian).

Ekserova, D., Kamchiev, D., \& Bamenov, B. (1983). Poverhnostnye sily i granichnyj sloj zhidkostej. M.: Nauka. (in Russian).

Fava, F., \& Danese, S. (2011). Intestinal microbiota in inflammatory bowel disease: friend of foe? World journal of gastroenterology, 17(5), 557-566. doi: 10.3748/wjg.v17.i5.557.

Iorhachova, K. H., Makarova, O. V., Hordiienko, L. V., \& Korkach, H. V. (2011). Tekhnolohiia kondyterskoho vyrob-nytstva. Praktykum: navch. posibnyk. Odesa: ONAKhT (in Ukrainian).

Kemsawasd, V., Chaikham, P., \& Rattanasena, P. (2016). Survival of immobilized probiotics in chocolate during storage and with an in vitro gastrointestinal model. Food Bioscience, 16, 37-43. doi: 10.1016/j.fbio.2016.09.001.

Kim, Y. S., \& Ho, S. B. (2010). Intestinal goblet cells and mucins in health and disease: recent insights and progress. Current Gastroenterolology Reports, 12(5), 319-330. doi: 10.1007/s11894-010-0131-2.

Konar, N., Toker, O. S., Sagdic, O., \& Oba, S. (2016). Improving functionality of chocolate: A review on probiotic, prebiotic, and/or synbiotic characteristics. Trends in Food Science \& Technology, 49, 35-44. doi: 10.1016/j.tifs.2016.01.002.

Korkach, A. V. (2015). Proizvodstvo zefira funkcional'nogo naznachenija. Materialy Mezhdunar. nauch.prakt. konf.: Aktual'nye problemy i perspektivy razvitija pishhevyh proi-zvodstv, gostinichnorestorannogo i turisticheskogo biznesa, Poltava, PUET, 67-69 (in Russian).

Korkach, A. V., \& Borovik, I. A. (2014). Razrabotka sinbioticheskoj dobavki i vlijanie ee na fizikohimicheskie svojstva zefirnoj massy. Materialy Mezhdunar. nauchnoj konf.: Pishhevye innovacii i biotehnologii, Kemerovo, 1, 105-107 (in Russian).

Korkach, A. V., Krusir, G. V., \& Borovik, I. O. (2014). Perspektivy ispol'zovanija sinbioticheskogo kompleksa v tehnologii zefira funkcional'nogo naznachenija. Vostochno-Evropejskij zhurnal peredovyh tehnologij, 2/12(2), 127-132 (in Russian).

Kostjukevich, O. I. (2011). Vlijanie kishechnoj mikroflory na zdorov'e cheloveka. Ot patogeneza $\mathrm{k}$ sovremen-nym metodam korrekcii disbioza. Rossijskij medicinskij zhurnal, 5, 304-308. URL: https:/www.rmj.ru/articles/gastroenterologiya/Vliyani e_kishechnoy_mikroflory_na_zdorovye_cheloveka_O t_patogeneza_k_ksovremennym_metodam_korrekcii_d isbioza/ (in Russian).

Krasina, I. B., Dzhahimova, O. I., Tarasenko, N. A., Demidov, A. V., \& Arakcheeva, O. N. (2008). Vafli s funk-cional'nymi svojstvami. Izvestija vuzov. Pishhevaja tehnologija, 1, 41-42. URL: https://cyberleninka.ru/article/n/vafli-s-funktsionalnymisvoystvami/viewer (in Russian).

Krasina, I. B., Hashpakjanc, E. A., \& Dzhahimova, O. I. (2014). Vlijanie probiotikov i prebiotikov na reolo- 
gicheskie svojstva strukturirovannyh dispersnyh sistem. Fundamental'nye issledovanija, 6, 1149-1153. URL: https://www.fundamental-research.ru/ru/article/view?id $=34303$ (in Russian).

Krugljakov, I. M., \& Ekserova, D. R. (1990). Pena i pennye plenki. M.: Himija (in Russian).

Mandal, S., Hati, S., Puniya, A. K., Singh, R., \& Singh, K. (2013). Development of synbiotic milk chocolate using encapsulated Lactobacillus casei NCDC 298. Journal of Food Processing and Preservation, 37(5), 1031-1037. doi: 10.1111/j.1745-4549.2012.00759.x.

Marushko, Yu. V., \& Asonov, A. O. (2018). Obhruntuvannia zastosuvannia synbiotyka optilakt Maliuk u pediatry-chnii praktytsi. Mizhnarodnyi zhurnal pediatrii, akusherstva ta hinekolohii, 12(1), 43-50 (in Ukrainian).

Peris-Bondia, F., Latorre, A., Artacho, A., Moya, A., \& D'Auria, G. (2011). The active human gyt microbiota differs from the total microbiota. PLos ONE, 6(7), e22448. doi: 10.1371/journal.pone.0022448.

Poznjakovskij, V. M., Vekovcev, A. A., \& Kardanova, M. M. (2005). Novyj vid molochnyh konfet funkcional'nogo naznachenija. Konditerskoe proizvodstvo, 3, 20 21 (in Russian).
Prakash, S., Tomaro-Duchesneau, C., Saha, S., \& Cantor, A. (2011). The gut microbiota and human health with an emphasis on the use of microencapsulated bacterial cells. Journal BioMed Research International, 2011, 1-12. doi: 10.1155/2011/981214.

Rad, A. H., Azizi, A., Darghahi, R., Bakhtiari, O., Javadi, M., Moghaddam, M. J., ... Pirouzian, H. R. (2018). Development of synbiotic milk chocolate enriched with Lactobacillus paracasei, D-tagatose and galactooligosaccharide. Applied Food Biotechnology, 5(2), 59-68. doi: 10.22037/afb.v\%vi\%i.19955.

Sushanskij, A. G., \& Lifljandskij, V. G. (1999). Jenciklopedija zdorovogo pitanija. T.1: Pitanie dlja zdorov'ja. SPb.: "Izdatel'skij dom "Neva". M.: "OLMAPRESS" (in Russian).

Zajkov, S. V. (2008). Narushenija mikrobiocenoza kishechnika: vsegda li neobhodimy probiotiki. Racional'na farmakoterapija, 2, 39-45 (in Russian).

Zubchenko, A. V. (2001). Fiziko-himicheskie osnovy tehnologii konditerskih izdelij: uchebnik. 2-e izd., pere-rab. i dop. Voronezh: Voronezh. gos. tehnol. akad. (in Russian). 